\title{
Taisa Kalennikova
}

Białoruski Technologiczny Uniwersytet Państwowy

Mińsk, Białoruś

\section{Студент - объект и субъект воспитания \\ The student as an object and subject of education}

https://doi.org/10.34739/sn.2019.19.12

\begin{abstract}
The article discusses the problems of educating students. Attention is paid to the formation of such character traits as independence, self-management, self-control, responsibility, sense of duty, etc.
\end{abstract}

Keywords: students, education, self-development

Резюме: В статье рассматриваются проблемы воспитания студенческой молодежи. Раскрыты возможности воспитательного потенциала курса «Основы психологии и педагогики». Уделено внимание формированию таких черт характера как самостоятельность, умение управлять собой, самоконтроля, ответственность, чувство долга и др.

Ключевые слова: студент, с образование, амостоятельность

Юность - пора самоанализа и самооценок. Самооценка осуществляется путем сравнения идеального «Я» с реальным. Но идеальное «Я» еще не выверено и может быть случайным, а реальное «Я» еще всесторонне не оценено самой личностью. Это объективное противоречие в развитии личности молодого человека может вызвать у него внутреннюю неуверенность в себе и сопровождается иногда внешней агрессивностью, развязанностью или чувством неполноценности.

Самая главная особенность юношеского образа состоит в осознании человеком своей индивидуальности, неповторимости в становлении самосознания и формирования образа - «я».

Человек создается не только воспитательным влиянием родителей, педагогов, прессы, телевидения и др., но и воспитывает себя сам. Как писал польский педагог Януш Корчак, воспитание без участия 
в нем самого ребенка не существует. Следовательно, оптимальное формирование личности, развитие сил и способностей предполагает взаимосвязь воспитания и самовоспитания, использования школы, вуза, общественной работы в интересах своего развития. По мнению белорусского ученого А.И.Кочетова - для развития способностей человеку необходимы трудности. Только при интенсивных нагрузках на пределе возможностей возникает озарение, вдохновение. Звездный час есть у каждого из людей, но к этому надо готовиться ежедневно, непрерывно, с полным напряжением сил.

Получение высшего профессионального образования позволяет молодому специалисту решать задачи разных уровней сложности. Выпускник вуза должен хорошо владеть не только специальными знаниями и умениями, но и психолого-педагогическими, которые помогут ему успешно адаптироваться к различным изменениям в социуме, прогнозировать ход развития той или иной ситуации, быть ответственным и инициативным.

Практика показывает, что психолого-педагогические знания и умения в современных услолвиях все более становятся межпрофессиональными и включаются в понятие «функциональная грамотность».

Учебный курс «Основы психологии и педагогики» способствует решению таких важных педагогических задач как:

- психолого-педагогическое обеспечение гуманитарного образования студентов;

- формирование у студентов способности к самопознанию и саморегуляции;

- формирование профессионально-значимых коммуникативных умений;

- формирование нравственных и трудовых качеств личности;

- формирование интереса к познанию как к важному условию и фактору развития личности.

K проблемам, связанным с самосознанием молодежи, следует отнести:

- недовольство собой;

- неуверенность в выбранной профессии;

- внутриличностные конфликты;

- неумение видеть свои проблемы; 
- критически оценивать свои собственные действия и поступки и др.

Следует отметить, что в настоящее время активно изменяется роль родителей и педагогов в реализации одной из основных функций трансляции опыта, знаний и культурных ценностей от старшего поколения к младшему. В силу того, что источником информации для юношества все чаще становится интернет, поэтому участие родителей и учителей в трансляции культуры значительно снижается.

Перед педагогами высшей школы стоит очень непростая задача:

- найти нужный тон в беседах со студентами;

- избежать назидательности, создать атмосферу заинтересованности и непринужденности, вдумчивости и серьезности;

- использовать в обучении современные технологии, которые будут способствовать развитию интереса к изучаемой проблеме.

Особое внимание в своей работе уделяем формированию у студентов таких черт характера, как умение управлять собой, пластичность, самостоятельность, выдержка, самообладание, самодисциплина, трудолюбие, самоконтроль. Так, на семинарских занятиях разбираем смысл такого понятия, как «самоконтроль». Студенты узнают, что среди механизмов, обеспечивающих надежность профессиональной деятельности самоконтролю принадлежит ведущая роль. Самоконтроль, как свойство личности, формируется в человеке под воздействием социального окружения. Несформированность самоконтроля, неумение им воспользоваться или нежелание к нему обратиться, пренебрежение его результатами - все это влечет за собой профессиональные неудачи, ассоциальное поведение, распад личности. Необходимо не только обучать человека навыкам самоконтроля, но и воспитывать в нем такие черты характера, которые бы побуждали его к должному самоконтролю в его поступках, поведении, деятельности. К ним следует отнести ответственность, дисциплинированность, чувство долга и др. Заостряем внимание на том, что в понятии «ответственность» акцент делается на способности человека предвидеть результаты своей деятельности, организовывать их исходя из того, какую пользу или вред она может принести обществу. Зрелость человека определяется не столько его биологическим созреванием, сколько тем, в какой мере он будет способен принимать на себя ответственность и контролировать собственные поступки. Судьба человека - это самопознание 
и самовоспитание. М.Горький указывал, что человек создает себя не благодаря, а вопреки обстоятельствам и доказал справедливость этого своей судьбой. К.Маркс отмечал, что если человек живет в неблагоприятных обстоятельствах, он на то и человек, чтобы сделать эти обстоятельства человечными.

При изучении темы «Самовоспитание личности» применяем моделирование различных ситуаций в рамках семинарского занятия. Так, студентам предложена анкета с вопросами:

1) Что я знаю о себе?

2) Какой я человек?

3) Какие способности я нахожу в себе?

4) Что я ценю в товарищах?

5) Каким я кажусь другим людям?

6) Какие недостатки я нахожу в себе?

7) Кем и каким я хочу быть после окончания вуза?

Анализ анкеты показал, что студенты недостаточно знают себя, поэтому отдельные неадекватно себя оценили. Только 6\% студентов указали на наличие у себя таких качеств, как ответственность, самостоятельность, умение управлять собой. На вопрос «Кем и каким я хочу быть после окончания вуза?» - $16 \%$ студентов ответило: «быть честным, добрым, иметь хорошую работу и семью». $11 \%$ указали на наличие у себя таких качеств, как: чрезмерная эмоциональность, неумение себя контролировать в ссоре, нетерпимость к другому мнению. На вопрос: «Какие способности я выделяю у себя?», только 1 студент из 30 ответил:

- способность здраво оценивать ситуацию;

- умение планировать и управлять своим временем;

- творческий подход во всех видах деятельности;

- логически мыслить.

Приводим в пример студентам программу самосовершенствования, которую составил для себя известный писатель Л.Н. Толстой в юности. Программа рассчитана на 2 года.

1. Изучать весь курс юридических наук, нужных для окончательного экзамена в университете.

2. Изучить практическую медицину и часть теоретической.

3. Изучить языки, французский, русский, немецкий, английский, итальянский, латинский. 
4. Изучить сельское хозяйство, как теоретическое, так и практическое.

5. Изучить историю, географию и статистику.

6. Изучить математику (гимназический курс).

7. Написать диссертацию.

8. Достигнуть средней степени совершенства в музыке и живописи.

9. Написать правила.

10. Получить некоторые знания в естественных науках.

11. Составить сочинения из всех предметов, которые буду изучать.

Программа нравственного самовоспитания требовала: постоянного анализа и оценки своих действий и поступков, преодоления вялости, инертности, пассивности путем развития воли; выработки умения понимать людей и помогать им; добиваться высокого качества выполняемой работы.

Среди пороков, от которых решительно отказался Л.Н.Толстой, были три: бесхарактерность, раздражительность и лень.

Под руководством куратора студенты включаются в воспитательные мероприятия, проводимые на факультетах, с большим интересом. Например, на факультете технологии органических веществ студенты участвовали в просветительской акции «Студенты за мир!». Эта акция включала: участие в конкурсе, викторине, мастер-класса по твистингу. В октябре на этом же факультете в общежитии № 4 проведен форум для иностранных студентов «Успешно учиться вместе!». Студенты из Камеруна, Туркменистана, Ирака ознакомились с презентациями актива факультета и членов студсовета общежития по следующим вопросам:

- особенности обучения в нашем университете;

- отлично учиться, чтобы стать успешным;

- Беларусь гостеприимная.

В ноябре на факультете проводился конкурс:

- на лучший гимн о факультете;

- на лучший логотип факультета и специальности;

- на лучший рекламный видеоролик;

- на лучшую листовку;

- на лучшую презентацию;

- на лучший рекламный текст. 
В декабре первокурсники приняли участие в конкурсе талантов «Минута славы».

На этом же факультете создан и много лет работает волонтерский отряд "Открытые сердца», который шефствует над детьми-сиротами и ветеранами Великой Отечественной войны и труда.

Велика роль кураторов групп на первом и втором курсах. Они помогают студентам адаптироваться к новым условиям, войти в социум вуза, включиться в активную деятельность. Так, на первом курсе проводятся следующие беседы: «Как учиться в вузе?», «Что мы знаем о нашей памяти?», «О воспитанности», «Как готовиться к экзаменам?», обсуждаются письма Д. С. Лихачева («Самая большая ценность жизнь», «Быть веселым, но не быть смешным», «Человек должен быть интеллигентом» и др.). Проводятся экскурсии в музей БГТУ, в Национальный художественный музей, в экологический центр, Дом правительства, на научные выставки и т.д. Организуются встречи с профессорским составом университета.

Участвуя во всех этих мероприятиях студенты развивают свою активность, самостоятельность, творчество, профессиональные интересы, лидерские качества, интеллектуальные потребности. Таким образом, у студентов постепенно развиваются способности к продуктивной деятельности, т. е. способности эффективно с высоким результатом трудиться. Как писал С. Л. Рубинштейн, «человек подлинно владеет лишь тем, что сам добывает собственным трудом».

Анкетирование, проведенное со студентами третьего курса ф-та ТТлП, показало следующую картину.

На вопрос: «Какие изменения произошли с Вами за время учебы в университете?» Ответы были следующие:

а) укрепила у себя волевые качества, целеустремленность, ответственность, стала более общительна;

б) изменила у себя упрямство, ленность, стала больше задумываться о будущем;

в) подтвердил позицию, что не зря пришел учиться на данный факультет;

г) стал более ответственным;

д) многое изменил в себе, можно сказать, что стал другим человеком. 
На вопрос: «Какое влияние оказала университетская среда на Вас?» Ответы:

а) университет оказал влияние на формирование рассудительности, здравомыслия;

б) стал более серьезный, подготовленный;

в) стала больше делать что надо, а не то, что хочется;

г) изменила свою самооценку;

д) научилась больше доверять людям, но и больше разочаровываться в них;

е) стала больше ценить родителей;

ж) стала более требовательна к себе;

з) большое влияние оказала на меня наша дружная группа.

На вопрос: «Не разочаровались ли Вы в своем выборе?» все студенты группы ответили, что они подтверждают и укрепляют свою позицию о будущей профессии.

Педагог и психолог А.И.Кочетов в своей книге «Как заниматься самовоспитанием» писал: «Самовоспитание - это открытие себя, выявление в первую очередь своих положительных свойств и возможностей и тех задатков, которые потом через самовоспитание человек может превратить в способности в талант, в устойчивую черту характера».

Самопознание - процесс долгий и сложный и чрезвычайно индивидуальный. Искать себя - это исследовать свое «Я» постоянно, в каждой новой ситуации, испытывать характер на преодоление трудностей.

\section{Literatura [Литература]}

Kalennikova T.G., (2013), Aktual'nyye problemyvospitaniya. Metod. rek. dlya kuratorov stud. grupp, BGT, Minsk, [Каленникова Т.Г., (2013), Актуальные проблемы воспитания. Метод. рек. для кураторов студ. групп, БГТУ, Минск].

Kochetov A.I., (1991), Kak zanimat'sya samovospitaniyem, Izd.3-ye., Vysh.shk., Minsk, [Кочетов А.И., (1991), Как заниматься самовоспитанием, Изд.3-е., Выш.шк., Минск]. 
Rangelova E., (2018), Vzaimodeystviye prepodavatelya i studenta: sostoyaniye i tendentsii, v: Vzaimodeystviye prepodavatelya i studentov $v$ usloviyakh universitetskogo obrazovaniya: traditsii iinnovatsii. Sbor. Nauch. dok., YEKS - PRES. [Рангелова Э., (2018), Взаимодействие преподавателя и студента: состояние и тенденции, в: Взаимодействие преподавателя и студентов в условиях университетского образования: традиции и инновации. Сбор.науч. док., ЕКС-ПРЕС]. 